\title{
Norsk forsøk på å gjøre Mekong til handelsvei for hundre år siden
}

\section{Eric Swane}

Like før Mekong-floden flyter fra Laos inn i Kampuchea, ligger det fire tusen små og store øyer i elveløpet. På øya Don Khone finnes det noen historiske minnesmerker. Nylig ble ruinene av et lite jernbaneanlegg restaurert og gjort tilgjengelig for turister. Åtte informasjonstavler forteller de besøkende om stedets historie.

En av tavlene har tittelen "Conquering Khone Falls” på den engelske halvparten. Plakaten er viet nordmannen Peter Hauff og den bragden han gjorde her, som ingen andre har klart før eller siden. Han fikk buksert sitt vesle dampskip opp forbi elvestrykene mellom øyene og det til tross for makthavernes motstand.

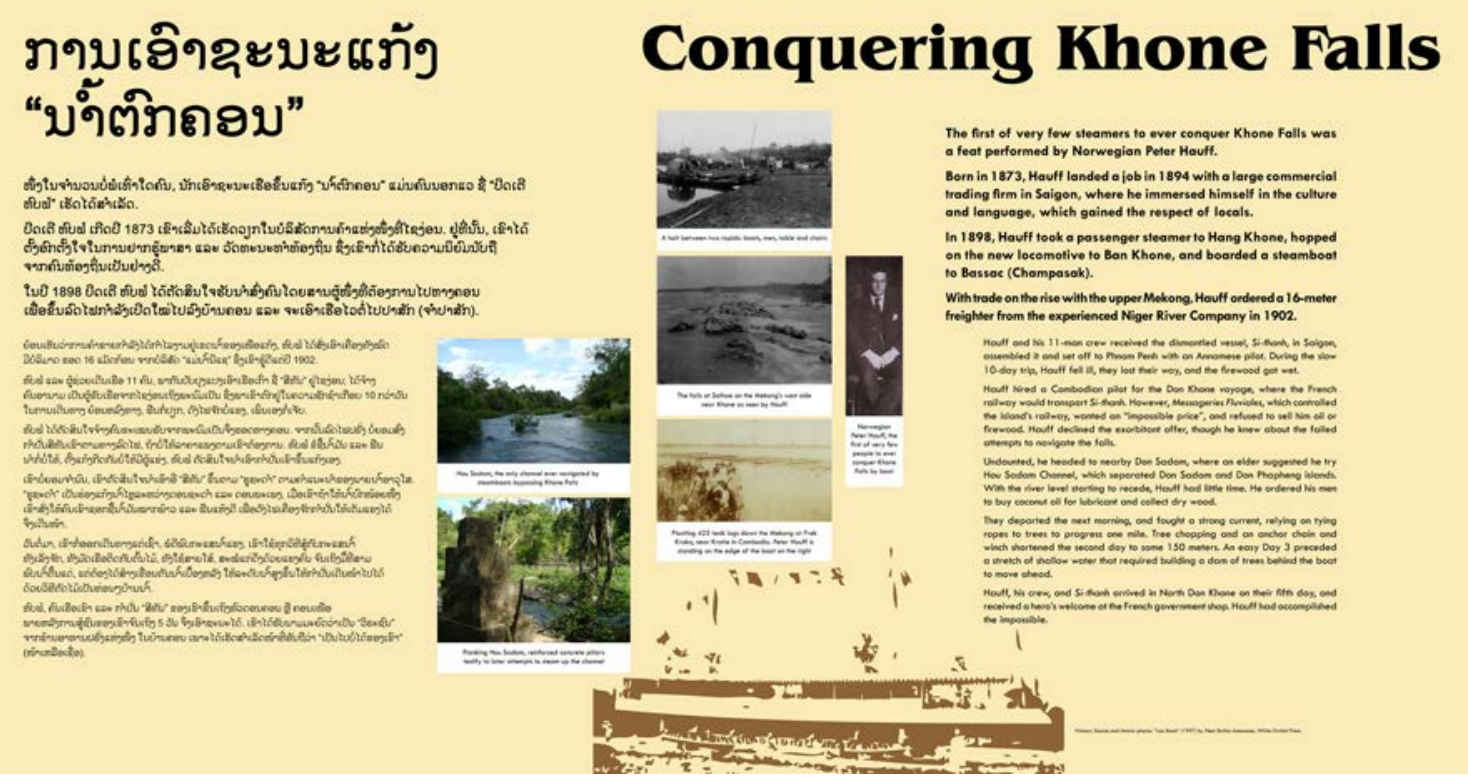

Bild 1. Informasjonstavle nr 8 på Khone [Don Khone]

\section{En lite påaktet historie fram i lyset}

Jean-Michel Strobino, som hadde forsket på og skrevet om den vesle jernbanelinjen på Khone [Strobino 1997], fikk oppdraget med å utforme tavlene [Don Khone]. Det var under arbeidet med dem at Strobino ble oppmerksom på Peter Hauff sine ferder på Mekong. Strobino ble så fascinert at han i tillegg til å tilegne en av tavlene til Hauff skrev en biografi om han nylig [Strobino 2013].

Hauff sin historie ble først offentlig kjent da hans barnebarn Fleur Brofos Asmussen utga boka Lao Roots i 1997 [Asmussen]. Forfatteren beskriver sin egen spesielle fami- 


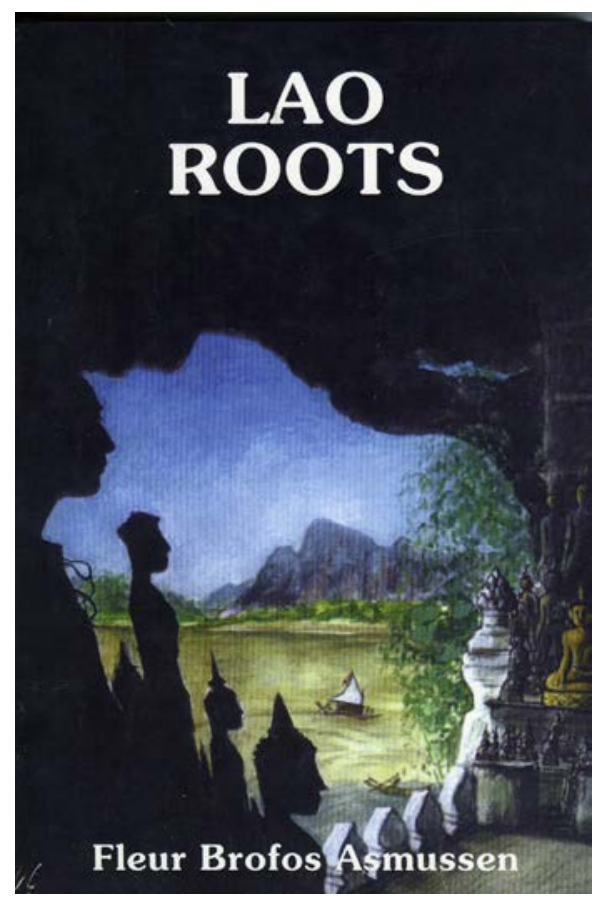

Bild 2. Lao Roots av Fleur Brofos Asmussen.

liebakgrunn, og den siste halvparten av boka er viet Hauffs historie. Hun har basert seg på dokumentene Hauff etterlot seg samt noe fra hans handelspartner Hans Rudolf Fäesch [Fäesch].

Da Hauff på 1930-tallet hadde flyttet tilbake til Europa, tok han fram sine gamle notater og dagboksopptegnelser og begynte å skrive en samlet beretning om sine opplevelser og observasjoner. Han prøvde i 1936 å få utgitt en bok med tittelen $M e$ kong: en norsk handelsmanns erfaringer i Indokina. Men forlaget han hadde kontakt med mente det ikke var interesse for stoff fra så fremmede steder. Det er her fristende å legge til at heller ikke Asmussen i vår egen tid fikk det lett og måtte langt avgårde for å få publisert historien.

Hauff etterlot seg et manuskript på seksti tett maskinskrevne sider, delvis på fransk og delvis på engelsk, som nok dannet grunnlaget for bokprosjektet hans. Det beskriver folk og levesett, men først og fremst reiser fulle av dramatikk og spenning. Ingrediensene smaker litt av film: vakker natur, ukjent og veiløst land, fremmede folk og kulturer, overvinning av tilsynelatende uoverkommelige hindringer, ukelange intense rafting-turer, skuddvekslinger med røvere, kamp mot konkurrenter, sykdom og dødsfall.

Det er bare romantikk og sex som mangler, men det fantes nok. Dagbøkene hans ble brent rett etter hans død, angivelig fordi de avslørte hans kvinnehistorier, som de etterlatte ikke ønsket å forholde seg til. Det er synd, for dagbøkene ville, helt generelt, ha formidlet hans umiddelbare inntrykk og reaksjoner dag for dag.

Hauff sendte sine to døtre født henholdsvis i Vietnam og i Laos til Europa og sørget for å gi dem god vestlig utdannelse. De to etterkommer-familiene her vest pleier regelmessig kontakt med sine slektninger i Sørøst-Asia. Selv om Hauff har monopol på sin egen historie, virker det ikke som at han i beretningene sine prøver å gjøre seg til helt. Han virker oppriktig glad i folk han møter og takknemlig for det han opplevde. Navn på steder, personer, firmaer og annet stemmer med andre kilder. De to handelspartnernes personlige fotografier gir beretningene liv og troverdighet.

Strobino sin biografi om Hauff [Strobino] konsentrerer seg om få fram hele Hauffs livsløp, i hovedsak basert på det samme materialet, men støttet og krydret med en og annen ny opplysning funnet andre steder. Den gjorde historien tilgjengelig for det fransktalende publikumet. Med det følgende gjøres historien ytterligere tilgjengelig, nå på norsk. Artikkelen gir et sammendrag av Hauffs forhold til Mekong og hans bestrebelser med å gjøre den til en lukrativ handelsvei. 
En kartskisse som gir oversikt over nedre del av Mekong og en del av stedene som omtales i denne artikkelen, er lagt til for oppslag sist foran referansene.

\section{Gled rett inn i det fremmede miljøet}

Peter Michael Vosgraf Hauff ble født i 1873 i Arendal, den gangen et viktig maritimt senter, spesialisert i skipsbygging og trelasthandel. Faren var skipper på langfart, men ble etterhvert havariagent $\mathrm{i}$ London og flyttet med familien dit. Hauff vokste opp med et vell av beretninger fra eksotiske strøk, og i London fikk han handelsutdannelse. Det var nok sterk motivasjon som fikk han til å ta rutebåten fra Marseille til Saigon knapt tjue år gammel.

Få dager etter ankomsten i Saigon begynte han å arbeide i et handelshus, og viste med en gang stor evne til å komme seg framover. Han skaffet seg raskt kontakter og venner, samtidig som han gikk i gang med å lære seg lokale språk. Det var et mylder av folkeslag og språk representert i byen. Primært lærte han seg landets hovedspråk, vietnamesisk, men innså snart at malayisk, takket være sin enkelhet og tydelighet, var språket som var gjengs å bruke innen handel. Derfor begynte han med å lære seg de få hundre malayiske ordene han trengte for å klare seg rent praktisk.

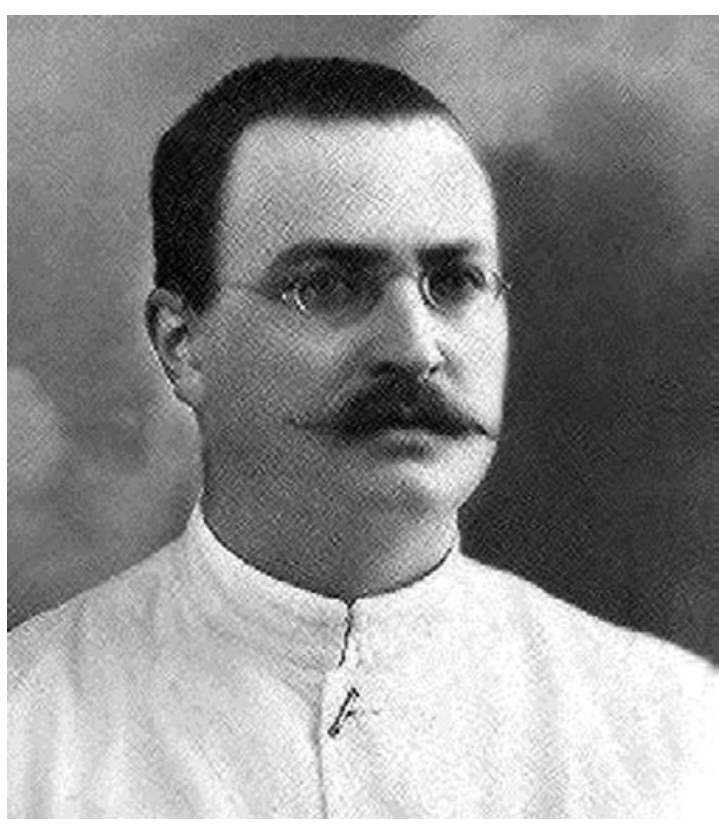

Bild 3. Peter Hauff.

Den dyktige kollegaen hans, A-Koun, halvt kineser og halvt vietnameser, var hans læremester. Han tok med seg Hauff til Cholon, den kinesiske byen i nærheten av Saigon. Få måneder etter ankomst kunne Hauff, ved å kle seg ut som kineser, med hatt som skjulte hårfargen sin, og ved å presentere seg som Peking-kineser som ikke behersket kantonsk men kun malayisk, klarte å bli med inn på klubber som ikke var åpne for hvite. Dette viser at han var lærenem og hadde en bemerkelsesverdig evne til å tilpasse seg til omgivelsene.

Hauff var representativ for en del europeiske eventyrere på den tiden, genuint interessert i alt han så og hørte. Han elsket å reise, se seg om og søke kontakt med alle slags folk. For å komme inn på vanlige mennesker, benyttet han helst de enkleste befordringsmidlene. Etter tre år i landet behersket han vietnamesisk så godt at han kunne gli naturlig inn i grupper av lokale folk, noe som ikke bare var hyggelig og praktisk, men også ga han prestisje.

Hauff skrev en god del om folkeslag og levevis, tradisjoner og religionsutøvelse, båtliv og fiske, matvaner og jordbruk, for å nevne noen sentrale temaer. Han beskrivelser er konsise og lite utmalende. Han er stort sett respektfull, men unngår ikke, ved minst en anledning, å karakterisere folks oppførsel som barnslig. Det var vanlig blant hvite i 
kolonitida, men vi vet ikke hvordan Hauff oppførte seg. Vi har bare hans egne ord, og han virket glad i mennesker.

\section{Mekong lokket på de moderne menn}

Hauff ble raskt lei av å bo på hotell i byen og bygget seg en liten hytte i Choquan, ved kanalen mellom Saigon og Cholon. Han var tiltrukket av vann og fikk bygd seg en seildukskano og fartet mye omkring. Elver og kanaler var ikke bare ferdselsårer, en stor andel av befolkningen bodde hele livet ombord på sine båter. Hauff ble fortrolig med dette miljøet og beveget seg stadig lenger vekk, antakelig helt inn i det enorme deltaområdet til Mekong-floden. Mekong betyr "vannenes mor" og den er den tiende største elven i verden når det gjelder transportert vannmengde. Den har sin kilde i Tibet, og der har den over halve lengden sin, før den skjærer gjennom den Sørøstasiatiske halvøya. Hauff følte nok tidlig en sterk dragning mot denne veien inn i det mer ukjente.

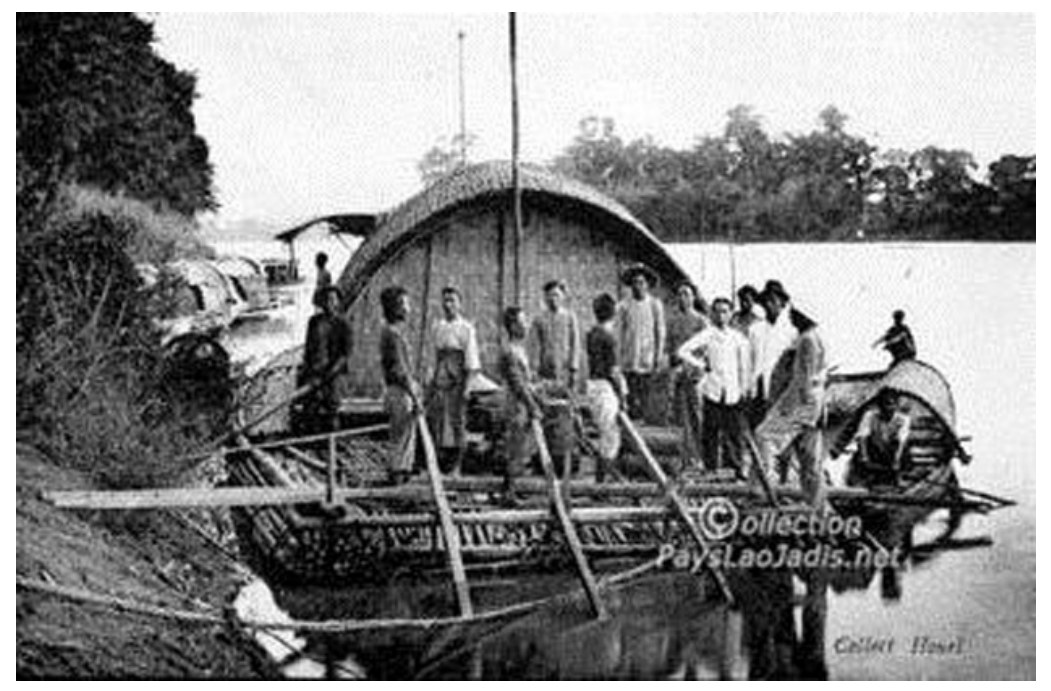

Bild 4. Postkort [Cartes] fra den aktuelle tidsperioden og gir et inntrykk av deler av båtlivet på Mekong.

Det var så vidt gått tretti år siden at franskmannen Garnier hadde ledet en to års ekspedisjon som ble den første til å følge Mekong fra utløpet og inn i Kina [Garnier]. Det var bare gått fem år siden staten Laos var blitt grunnlagt som fransk koloni. På samme tid hadde et fransk selskap opprettet noen båtruter på Mekong, og kartlegging og merking av elveleiet, samt utbygging av et telegrafnett, pågikk. Gode kommunikasjoner var viktige for å kunne opprettholde en koloni, og franskmennene så for seg Mekong som en kommersielt viktig ferdselsåre, ikke minst som en hovedvei til det indre Kina.

Garnier hadde blitt skuffet over det han oppdaget og beskrev elveløpet i detalj i sin bok. Det fantes betydelige strekninger der elva fløt bred og rolig og innbød til moderne skipsfart. Men dessverre var disse avbrutt av fem vanskelige områder preget av stryk og fosser eller av trange og dype slukter der vannstrømmen bygde seg rask og sterk og dannet farlige strømvirvler. Framkommeligheten var sesongavhengig, bestemt av nedbør og issmelting langs hele elva oppstrøms. 
På disse strekningene kunne en bare bruke kanoer (piroger, hultrebåter) eller solide flåter, og en måtte padle, stake, hale, slepe og bære disse og deres last forbi hindringene. Tilfeldige steinblokker og trær flytende rett under overflaten var lumske.

Drømmen om å la moderne skip gå uavbrutt langs elva måtte oppgis, men det ble utviklet et transportsystem fra kysten og inn i Laos. Da rutebåttilbudet var på sitt beste i 1930-årene, var reisetiden fra Saigon til Luang Phrabāng stipulert til trettisju dager, noen dager mer enn til Marseille. Da måtte passasjerene skifte fartøy sju eller åtte ganger underveis. Alle omlastingene gjorde at fraktgods trengte langt mer tid på å nå fram. På strekningen på drøye 2600 kilometer er fallet på under to hundre meter, og det er ikke stort i gjennomsnitt.

\section{Satset på Mekong som handelsvei.}

I april 1898 startet Hauff sin personlige utforskning av Mekong. Hva tanken med reisen var, vet vi ikke sikkert. En stor trang kan simpelthen ha bygd seg opp i løpet av fire år i Saigon. Reiste han for fornøyelsens skyld, eller var trangen til forandring begynt å murre? Han må ha hatt hørt en del om forholdene både på elva og i området innenfor, og det lokket tydeligvis mer enn det skremte.

Båtturen til Phnom Penh og videre til Kratié var og er som en sjøreise å betrakte. Videre var elva grunn, og Hauff reiste alene på en stor kano med et mannskap på elleve laotiske menn. Hauff likte dette folkets væremåte og hygget seg på turen. De forserte Sâmbor-fallene, og der strømmen var sterk, måtte båtene møysommelig stakes meter for meter, og der det var dypt, trekkes etter trærne. Hauff overnattet på bunnen av båten, men sier ikke hvor mange netter det ble. Ved Stung Treng, femti kilometer før dagens grense til Laos, gikk Hauff ombord i en liten damper, som gjorde sin etappe unna på seks timer.

Han ankom Khone-området, tradisjonelt kalt Si Phan Don, laotisk for "fire tusen øyer". Her favner Mekong bredt, deler seg i utallige løp, alle med stryk eller fosser. Her ligger den største hindringen for ferdsel på Mekong, og i årene forut for Hauffs ankomst var det gjort mange og tildels heltemodige forsøk på å finne en farbar vei gjennom labyrinten. Hauff og andre passasjerer ble befordret over øya på en sju kilometer lang jernbane, bygd av franske myndigheter få år tidligere for å bringe to kanonbåter forbi og inn i Laos. Han gikk ombord i en ny damper og var framme samme kveld i Không, den gangen administrasjonssenter for Sør-Laos.

Han reiste en dagsreise til oppover til rutebåtens endepunkt, tvers over for dagens Paxsé. Der ble han værende ombord for umiddelbart å bli med nedstrøms. Dette vendepunktet for jomfruturen hans ble også et vendepunkt i livet hans. Han hadde konstatert at regionen var rik på ressurser, og at det fantes flere typer råvarer han kunne kjøpe opp for eksport. Lokalbefolkningen var relativt ubemidlet, men det burde være marked for billige industrivarer. Det fantes noe handelsvirksomhet, drevet av kinesere, med transport gjennom Thailand. Hauff mente Laos hadde en lysende framtid og ønsket å være med på den forventede utviklingen. Han hadde gode relasjoner til franske myndighetspersoner, 
og kolonimakten oppmuntret til slik økonomisk aktivitet. Hauff bestemte seg for å bli den første hvite handelsmann i Laos, basert på Mekong som transportvei, for eksport og import over Saigon.

\section{Europeiske handelspionérer i Vientiane}

Hauff og hans nye partner Fäesch forlot Saigon 4. desember 1898 med Vientiane i Laos som mål. De hadde med seg to hundre og femti kasser og baller med utstyr og materialer samt varer for salg. De reiste stort sett på samme måte som tidligere, men denne gangen trengtes sju kanoer med mannskap. Underveis måtte de forsere den vanskelige strekningen ved Khemarat, midt mellom Paxsē og Savannakhēt. De møtte masse hyggelige mennesker, og franskmenn inviterte dem til gode måltider. De var framme etter tre og

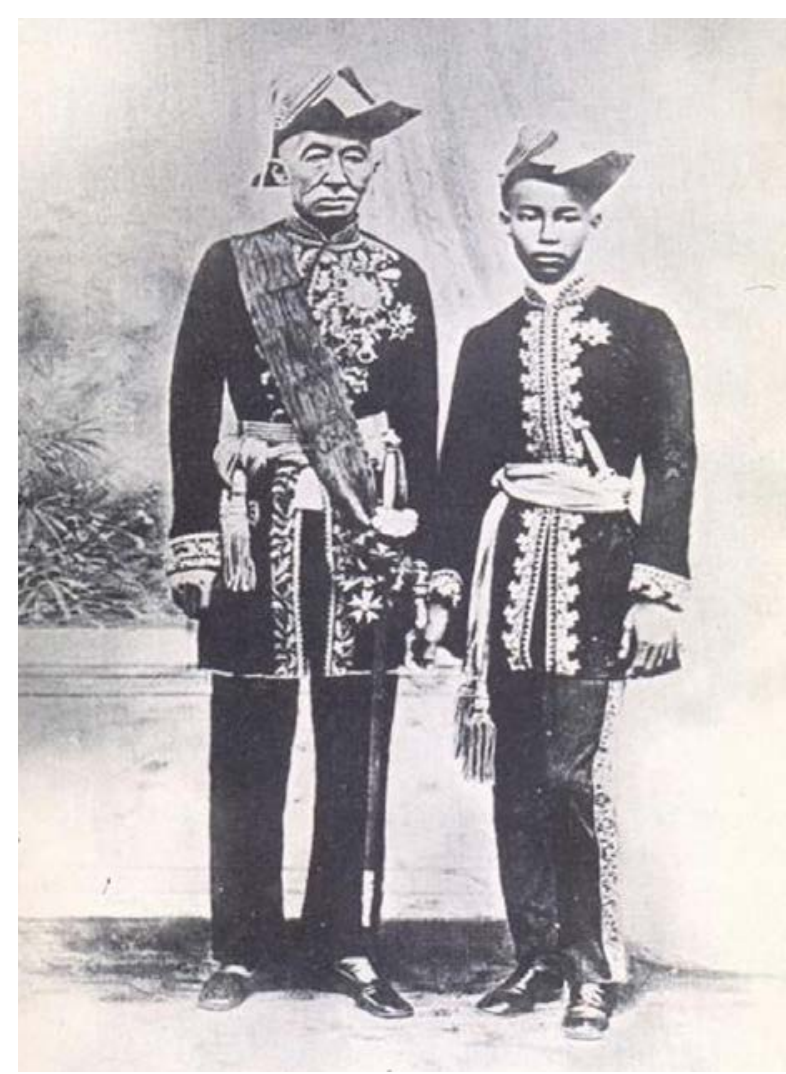

Bild 5. Kong Mongkut og prins Chulailongkorn. halv måned, men da hadde de hatt opphold og avstikkere underveis og fått prøvd ut markedet for varene sine.

Et lite sverd som er i familiens eie, er et minne fra denne turen. Hauff og Fäesch tok en avstikker inn i Thailand. De gikk til fots åtti kilometers opp langs side-elva Moun til Oubon. Der ble de tatt i mot av den lokale guvernøren, visekongen Sadet Khrom Kun San Rasit, og han skjenket Hauff sverdet. Han var bror av kongen, Chulailongkorn, gjerne kalt den store, fordi han reformerte Thailand til en moderne stat.

Mens det fins masse skrevet om Chulailongkorn, er det lite å finne om hans bror guvernøren. Det er kanskje ikke så merkelig, for deres far, kong Mongkut, hadde 82 barn og 39 koner, for ikke å snakke om et harem på ni tusen kvinner. En engelsk kvinne som Mongkut ansatte for å besørge barnas utdannelse, skrev flere bøker som skildret hoffmiljøet. Det ble grunnlaget for den store Broadway-musikalen "The King and I", som også fins i flere filmversjoner. Det kan tenkes at guvernøren som Hauff traff, figurerer i en birolle i stykket.

Det var først da de kom til øvre Laos og Vientiane, der folk var noe rikere, at de fikk suksess med varene sine, spesielt hos kvinnene. I løpet av de neste to år fikk de bygd seg en kombinert butikk og bolig og et lagerhus. De fikk enda en partner, og de tre byttet om på å reise i hele området, opp til Luang Phrabāng, vurdere forholdene og verve innkjøpsagenter. 


\section{Utfordret kolonimaktens rutebåtmonopol.}

Under avstikkeren til Thailand fikk de første erfaringene med hva frakting av varer innebar. Ryktene om deres oppkjøp av huder spredte seg raskt blant de lokale, og snart hadde de samlet åtte tonn. Da måtte de leie to store bemannede kanoer for å bringe varene tilbake ned Moun-elva til Mekong. Underveis ble de først angrepet av banditter, og siden tvunget til å losse og bære alt forbi en foss de ikke var forberedt på. De kom seg til rutebåtens stoppested og sendte varene nedover med den.

Etter få måneder i Vientiane innså de at rutebåten ikke hadde kapasitet til vareforsendelsene deres og at de måtte besørge transporten selv. Hauff fikk hogd masse bambus og bygde med det en stor flåte han døpte "Hoppy". Den ble lastet opp med førti tonn varer, og med et mannskap på fjorten mann og noen ekstra kanoer reiste Hauff på tampen av juni 1899 nedover Mekong.

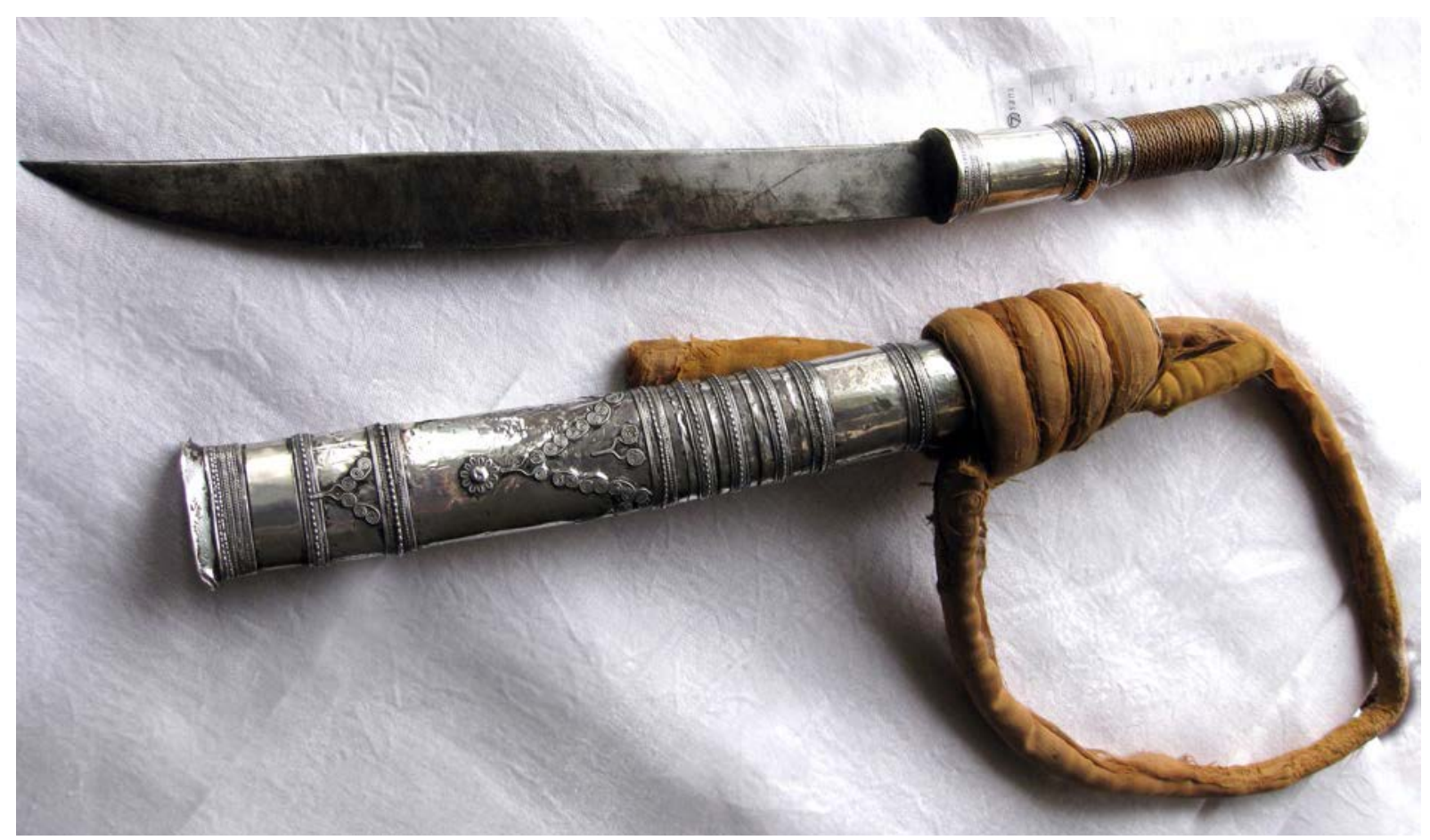

Bild 6. Gaven, et Thai kortsverd. Bladet er omlag $30 \mathrm{~cm}$ langt.

I sin beretning om denne friske rafting-turen sier Hauff at de kom fram til Khone uten større uhell, men det skjedde unektelig en del dramatikk underveis. Godset ble derfra videresendt med rutebåten, mennene ble sendt opp igjen med båtene, og Hauff tok seg en velfortjent ferie for å restituere seg etter skader og feilernæring ombord. Kanskje var det da tanken om å løpe linen helt ut, og få seg sitt eget dampskip, ble unnfanget.

Hauff hadde en bror i London som var ingeniør. Ingeniøren fant den rette konstruktør til å bygge en mindre dampbåt egnet for forholdene på Mekong. Den ble femtito fot lang, kunne laste tretti tonn og gjøre tolv knop. Den ble sendt via Marseille i løse deler, men da ruteskipet ble rekvirert til troppetransport, ankom byggesettet Saigon seint i 1902, to måneder etter planen og etter at regntiden var slutt. 
Hauff, som aldri hadde sett en teknisk tegning, klarte å få satt sammen båt og maskin. Fjorten dager etter ankomst ble den vesle damperen sjøsatt og døpt "Si-Thanh" (et mannsnavn). De reiste umiddelbart mot Phnom-Penh og videre til Kratié. Hauff skriver om diverse problemer på denne etappen, men damperen klarte tydeligvis å forsere strykene ovenfor med glans.

Ved Khone hadde Hauff regnet med å få fraktet damperen sin forbi det uframkommelige partiet på jernbanestumpen nevnt tidligere. Men den var nå overtatt av båtruteselskapet, og de ønsket ikke konkurrenten velkommen og krevde derfor en uforholdsmessig høy pris for å befordre båten. Da besluttet Hauff seg for å få båten forbi selv, koste hva koste ville.

Vannstanden sank stadig, så de måtte skynde seg med forberedelser. Så fyrte de dampmaskinen hardt, og ved hjelp av propeller, vinsjer, oppfinnsomhet og iherdighet, kunne de etter fem døgn seile inn foran kontorene på oversiden og blåse i fløyta. Dette vakte stor oppsikt, for mange hadde før jernbanen kom, prøvd det samme. Dette er, her nøkternt kort fortalt, bragden som Hauff nå er belønnet med egen informasjonstavle på Khone.

Vannstanden hadde da sunket så mye at ruten videre ikke var farbar. Da innså også Hauff at Mekong aldri kunne bli noen pålitelig helårs transportvei, og han bestemte seg for å selge "Si-Thanh”. Det såkalte ”De hellige menns opprør” i Thailand spredte seg til Laos. Båtruten videre var innstilt, så Hauff måtte ta beina fatt gjennom jungelen langs telegraflinjen, enda en kraftanstrengelse. Da han kom hjem, fant han Fäesch alvorlig dysenteri-syk, og opprøret hadde skapt lovløshet og kaos. Mange av underleverandørene var døde eller hadde flyktet, og utbetalinger av forskudd for varer var tapt. Det roet seg imidlertid snart, i alle fall lokalt, og hverdagen kom tilbake.

\footnotetext{
Hauff hired a Cambodian pilot for the Don Khone voyage, where the French railway would transport Si-thanh. However, Messageries Fluviales, which controlled the island's railway, wanted an "impossible price", and refused to sell him oil or firewood. Hauff declined the exorbitant offer, though he knew about the failed attempts to navigate the falls.

Undaunted, he headed to nearby Don Sadam, where an elder suggested he try Hou Sadam Channel, which separated Don Sadam and Don Phapheng islands. With the river level starting to recede, Hauff had little time. He ordered his men to buy coconut oil for lubricant and collect dry wood.

They departed the next morning, and fought a strong current, relying on tying ropes to trees to progress one mile. Tree chopping and an anchor chain and winch shortened the second day to some 150 meters. An easy Day 3 preceded a stretch of shallow water that required building a dam of trees behind the boat to move ahead.

Hauff, his crew, and Si-thanh arrived in North Don Khone on their fifth day, and received a hero's welcome at the French government shop. Hauff had accomplished the impossible.
}

Bild 7. Panelteksten om selve forseringen av Mekong ved Khone [Don Khone]. 


\section{Unik og omfattende tømmerfløting}

I 1903 fikk Hauff uventet en forespørsel om han kunne påta seg oppgaven å føre et parti teak fra Luang Phrabāng ned til kysten. Jobben var godt betalt og inntekten ville komme godt med slik økonomien var. Tolv hundre stokker med lengde opptil femtifem fot og diameter opptil fire fot ble samlet i flåter. Hauff var så vidt i gang da han fikk telegram om at Fäesch var død, og da han senere passerte Vientiane, fikk han konstatert at alt de eide, inklusive hans egne personlige eiendeler, var solgt på auksjon. Da var det fint å ha en jobb å leve av og konsentrere seg om.

Første etappe gikk uten større uhell, men var et blodslit. Sammenbindingen av flåtene krevde kontinuerlig vedlikehold, antall og størrelse på flåtene måtte stadig tilpasses elvas beskaffenhet, og fortøyningen av dem hver kveld var arbeidskrevende. Ved Khone ble det pause i påvente av neste regntid, og Hauff fikk et halvt års tiltrengt hvile i Saigon.

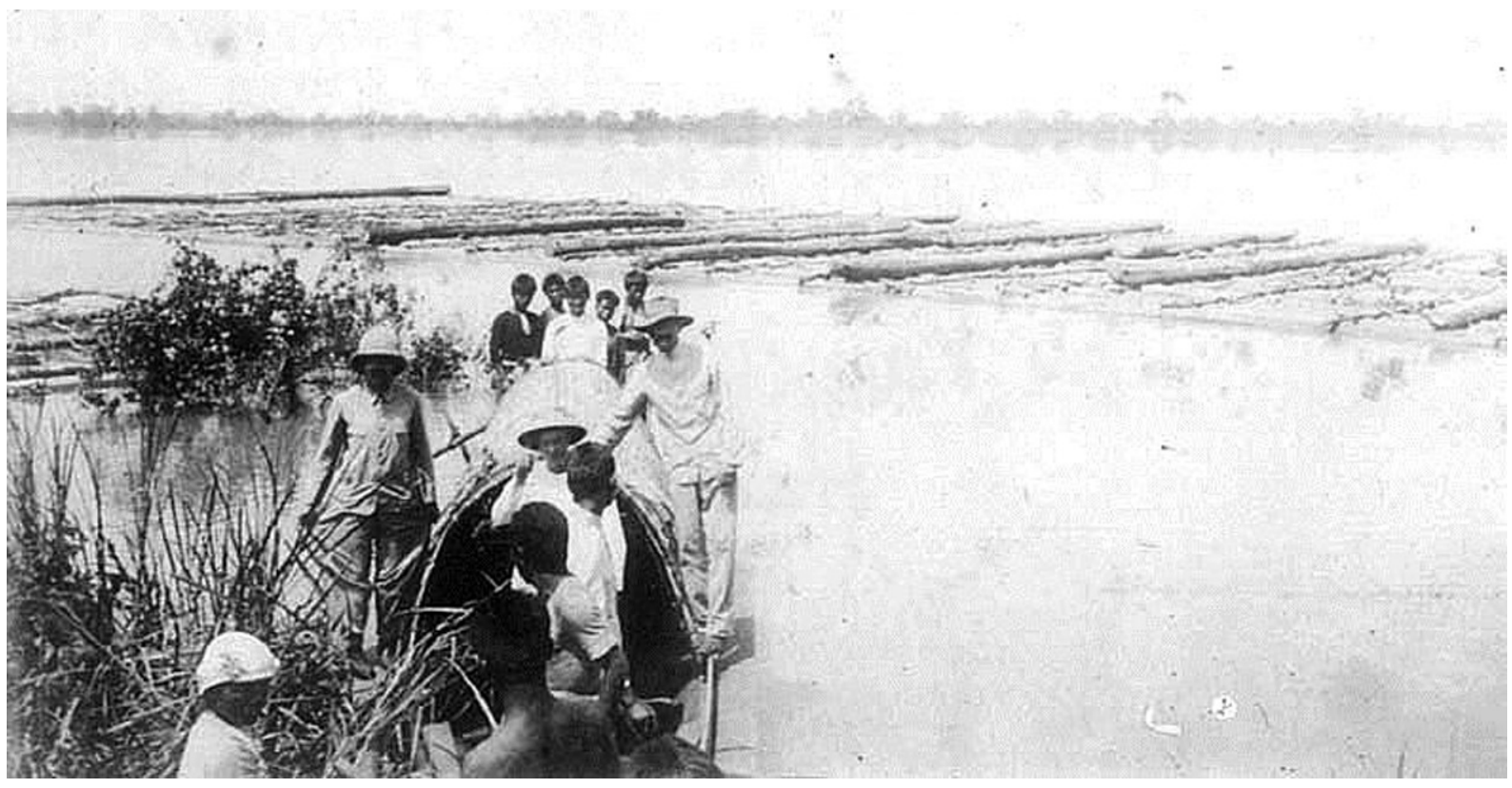

Bild 8. Med 425 teakstokker i rolig farvann ved Kratié. Hauff stående på båtripa lengst til høyre.

På andre etappe i 1904 fikk Hauff med seg den laotisk-talende franskmannen Guy Cheminaud som nestkommanderende, og det var sikkert bra, tatt i betraktning alt som skjedde. Delta-området med sine brede elveløp, labyrintaktige kanalsystem og uforutsigelige strømmer bød absolutt på utfordringer.

Det hele må ha tatt godt over et år. Gjennomføringen vitnet om stor standhaftighet, men dette banet ikke noen anvendbar vei for tømmerfrakt fra det indre. Verdien av teak var muligens så høy, og arbeidskraften så billig, at foretakendet ble lønnsomt, men det kostet også menneskeliv, skade på eiendom og for lokalsamfunnene masseslagsmål og trafikk-problemer. 


\section{Ble nesten konform handelsmann}

Handelen i regionen blomstret aldri slik Hauff håpet. "De hellige menns opprør” angikk ikke Laos eller kolonimakten direkte, men spredte en ustabilitet som vedvarte til 1910, da lederen døde. Deretter fulgte mer uro da kommunistopprør og stridigheter omkring opiumshandel brøt ut. Etterhvert fikk kinesere og vietnamesere utviklet jordbruk og handel, men transporten ut i verden gikk over Thailand, den raskeste og letteste veien, spesielt da jernbanenettet der nådde Mekong på slutten av 1920-tallet.

I kappløpet om kolonier på siste halvdel av 1800-tallet, og etter å ha blitt ydmyket i krigene mot Tyskland, hadde Frankrike så seint som i 1893 annektert det som skulle bli Laos. Men dette tynt befolkede og avsondrede området var og forble en bakevje. Mekong var egnet verken til å forbinde landet med resten av det franske Indokina, eller bli en lukrativ vei til Kina. Franske myndigheter spanderte aldri ressurser på å utvikle området, for eksempel ved å bygge et slusesystem i Mekong, men satset heller på veier. Allerede på 1930-tallet fikk Vientiane helårs veiforbindelse til Saigon.

Slik sett var det neppe noen grunn for Hauff å gjenoppta handelsvirksomheten sin der. Spørsmålet er om virksomhetens hans var dømt til å mislykkes uansett. Ville, selv uten

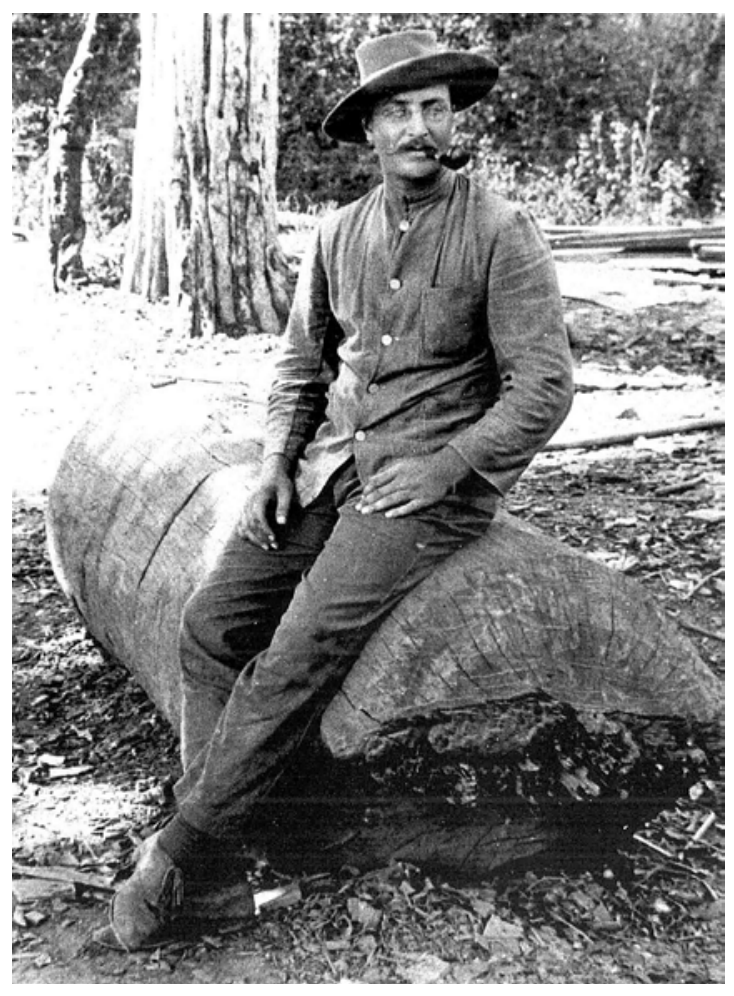

Bild 9. Hauff under tømmerfløtingen. sykdom, opprør og motarbeidelse av båtruteselskapet Mekong aldri ha blitt noen kommersielt lønnsom transportvei? Slike konklusjoner stod i hvert fall å lese i litteraturen allerede fra 1870-årene, spesielt den engelske, der franskmennenes framstøt i det indre Indokina nærmest ble gjort til latter.

Det hadde vært interessant å vite hvordan Hauff selv, den gangen, vurderte dette. Ut i fra hans beretninger kan det virke som at han og partnerne tjente godt i perioden før de ytre begivenhetene ødela for dem. Det kan synes som at marginene var mer enn gode nok til å kompensere for den tunge og dyre transportruten og den risikoen de visste de løp ved å operere så langt fra allfarvei. Det fins ingen oversikt over den økonomiske virkeligheten bak foretakendet, hvordan de finansierte det hele, hvor stort det reelle overskuddet ble og om andre enn dem selv til slutt tapte innsatsen sin.

Hauff hadde mistet alt i Laos, bortsett fra den familien han hadde stiftet der. Begge partnerne hans hadde mistet livet, og han selv hadde vært svært syk ved flere anledninger. Disse årene har hatt stor betydning og formet han som voksen mann. Det ble den ypperste dannelsesreise, som unge mennesker anbefales å ta seg i dag, men av et kaliber som selv de dristigste backpackere i dag kan drømme om. 
Hauff la seg snart i konformitetens fold, giftet seg med en norsk kvinne, dannet familie etter vestlige normer, satset på et forutsigbart utkomme og var i de følgende to tiår en dannet borger av Saigon. Men han sluttet aldri med å utfordre seg selv med ulike typer handelsprosjekter. Da han senere flyttet til Sør-Frankrike, etablerte han en elektrobutikk, som vokste til en butikkjede, men nok en gang tapte han alt, denne gangen på grunn av den andre verdenskrigen.

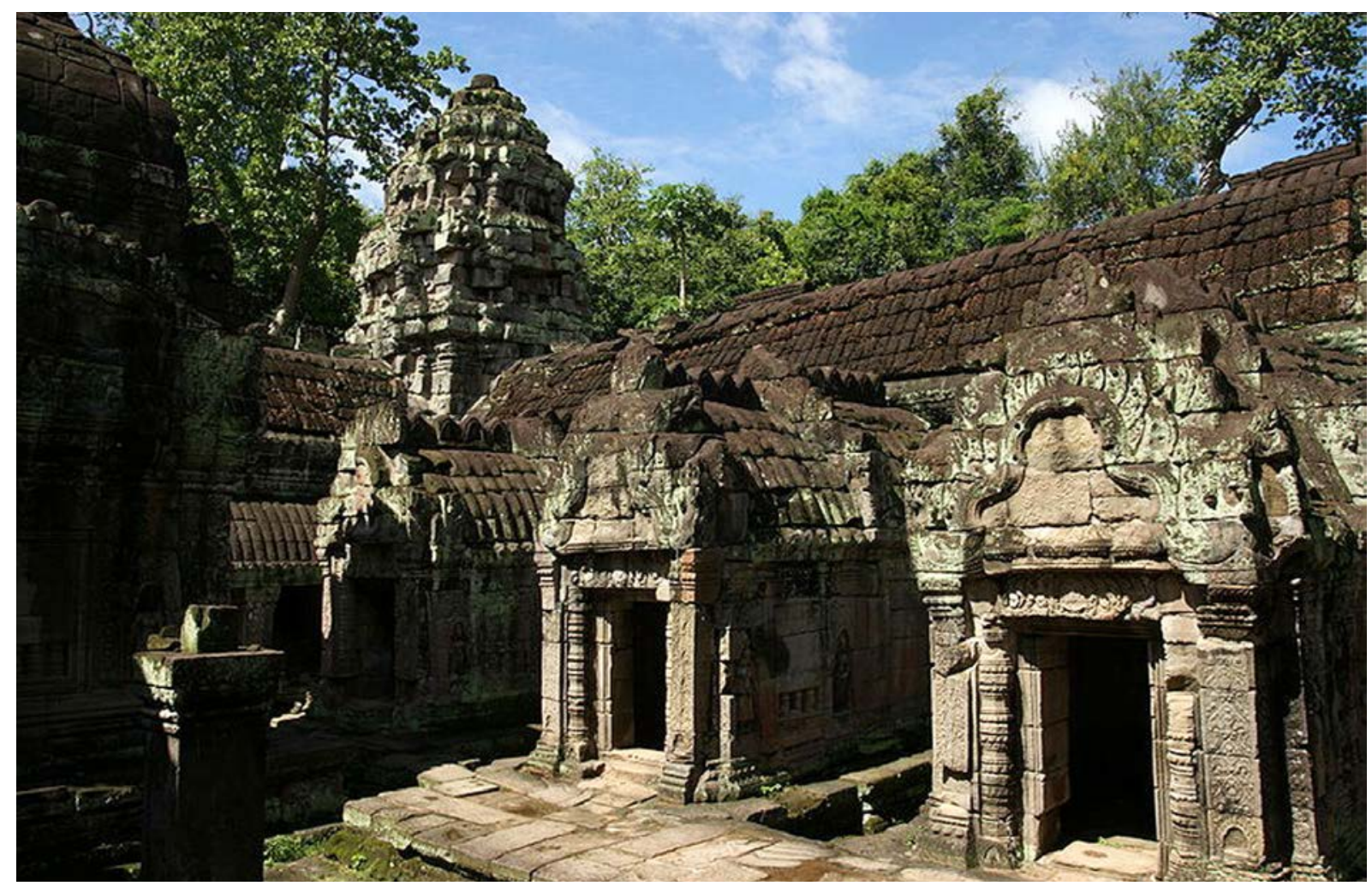

Bild 10. Parti fra Prah-Khan.

\section{Kunne nok fortalt så mye mer}

Hauff fortsatte å reise omkring i Indokina, noe som handelsmann, men etterhvert kanskje mer som turist. Han ble spesielt betatt av det store og nå berømte tempelkomplekset Angkor Vat, som han besøkte fire ganger.

I 1923 utga Hauff en liten roman på norsk med denne tittelen Drømmen i Prah-Khan [Michael]. Preăh Khăn betyr "kongelig sverd” på Khmer-språket og er et tempel bygd i det tolvte århundret, på utkanten av Angkor. Boka ble ingen bestselger og framstår i alle fall i dag som banal. Det er en rett-fram, tør vi si romantisk, fortelling med innskutte dikt. En del av stoffet har Hauff åpenbart hentet fra sine egne opplevelser i Sørøst-Asia, så i utgangspunktet har det interesse å se nærmere på boka.

Den første tredjedelen av boka beskriver hovedperson Lars sitt liv i Norge og de unge damer som har vekket hans interesse. Lars får kontorjobb i et handelshus i Liverpool, men han vil helst komme seg ut og får etterhvert oppdraget med å fløte et stort parti tømmer ned langs elva Mekong. Underveis besøker Lars det store ruinområdet Angor Wat, siden også ruinene av templet Prah-Kahn, der han sovner og får en drøm. Når han er 
tilbake i Norge, får han en av nevnte damer, som forærer han en pyntenål med innskrift av "forstaaelige ord for alle tre i belysning av drømmen i Prah-Kahn". Der slutter boka.

Boka er like fengslende som sammendraget ovenfor. Hauff skusler bort anledningen til å skildre eksotiske miljøer og til å legge inn spennende historier. Tømmerfløtingen til Lars ofres en halv sides nøkternt referat. Hauffs egen bragd med å bringe et stort parti teak 2600 kilometer ned Mekong, som i ettertid er den som står igjen etter han i de lokale historiebøkene, kunne vært gjort til et høydepunkt i romanen.

\begin{abstract}
i den mest ugjennemtrængelige urskog. Der er en ruin især som tiltrak Lars og som han ikke skulde komme til at glemme.

Den heter Prah-khan og Lars hadde der et drómmesyn som satte merker for livet. Han bes $\phi$ kte Prah-khan $f \varnothing$ rste gang i f $\phi$ lge med en kjendtmand og det tok dem flere tiñer at komme igjennem bygningen fra ende til anden, Lars lovet sig selv han vilde komme tilbake og bese nøiere noen av de underjordiske ganger. - Det gjorde han
\end{abstract}

Bild 11. Utdrag fra boka.

Det artige med boka er at den inneholder en rekke selvbiografiske elementer helt på detaljnivå. Et eksempel blant mange er at da Lars i Prah-Kahn hadde skadet seg i foten, traff han på den franske arkeologen som arbeidet i området og fikk hjelp av denne til å forbinde foten. Slik skjedde det med Hauff i virkeligheten. En del tanker som dukker opp i romanen kan en anta er Hauff sine, så boka supplerer manuskriptet hans ørlite grann. Han sier for eksempel at en bør vinne innleide mannskaps tillit ved å være etterrettelig og upartisk. I hvert fall gir romanen kanskje et hint om at Hauff i sine manuskripter ikke på noen måte fikk formidlet alt det han hadde erfart og opplevd.

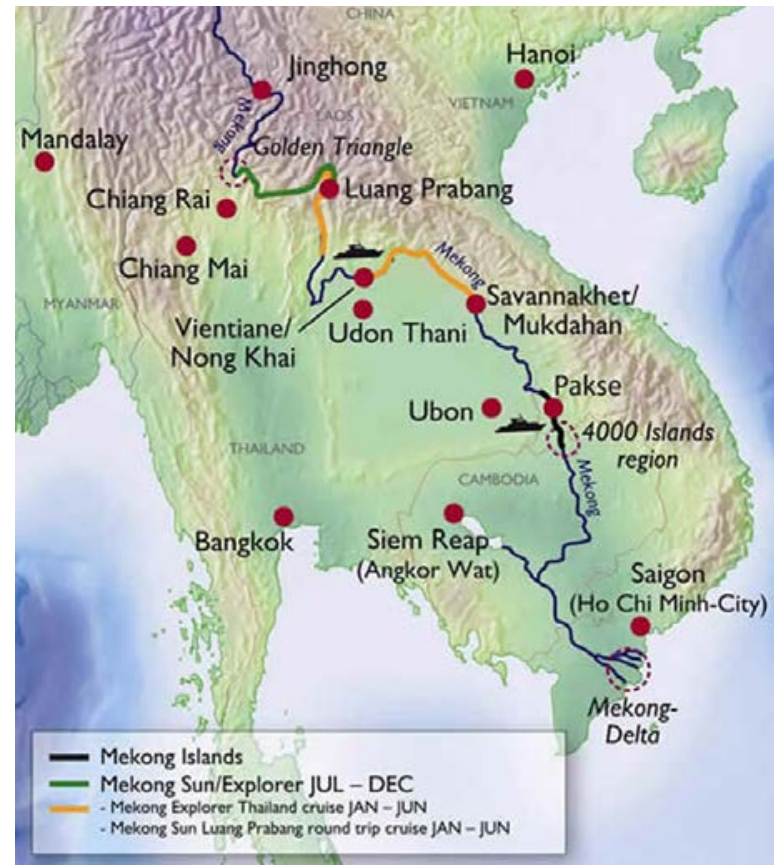

Bild 12. Oversiktskart lånt av et elvecruiseselskapet [Unique].

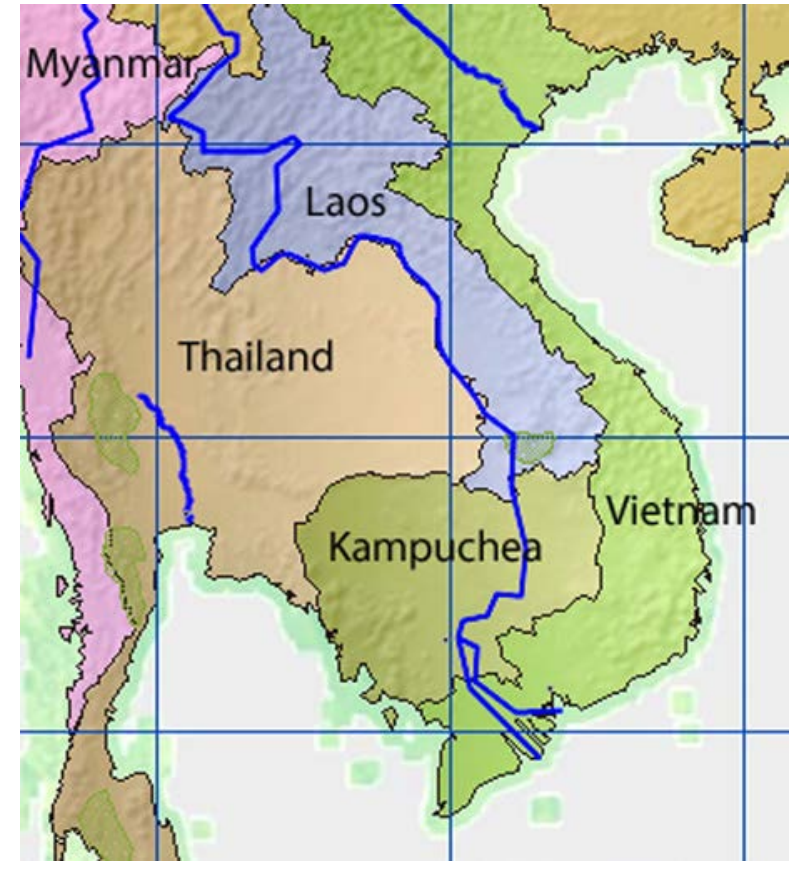

Bild 13. Indokina. 


\section{Referanser}

Asmussen, Fleur Brofos (1997), Lao Roots, Bangkok: White Orchid Press.

Cartes Postales Anciennes et Modernes du Laos, http://cpalaos.cabiddu.net/index.php .

Don Khone Railway Pavillions Panels, http://www.stdplaos.com/downloads/web-based knowledge center/visitor information/provinces in laos/champasak/Don\%20 Khone\%20Railway\%20Pavillions\%20Panels.pdf .

Faesch, Hans Rudolf (1906), 'Erlebnisse eines Basler Kaufmanns in Laos (Indo-China). Autobiographische Skizzen’ Basler Jahrbuch bind 26 side 49-84. Basel.

Garnier, Francis og Gomane, Jean-Pierre (1885), Voyage d'exploration en Indochine. Paris: Hachette 1885 (mange nyere utgaver og på Internett, http://collin.francois.free.fr/Le_tour_du_monde/textes/Indochine1/Chapitre1.htm ).

Michael , Peter (1923), Drømmen i Prah-Khan. Kristiania: Norske forfatteres forlag. Osborne, Milton (2000), Chapter 8 'Navigating the Mekong: Challenge, Illusion and Defeat', i Osborne, Milton The Mekong: Turbulent Past, Uncertain Future. Sydney: Allen \& Unwin.

Strobino, Jean-Michel (1997), 'Laos: le chemin de fer des canonnières', i La Vie du Rail nr 2329: jan 1997, http://www.anai-asso.org/NET/document/loeuvre de la france/ loeuvre de la france/infrastructures terrestres et portuaires/les voies ferrees/le chemin de fer des canonnieres/index.htm .

Strobino, Jean-Michel (2013), Peter Hauff (1873-1951), Les Avantures d'un Marchand Norvegien en Indochine au Debut du XX-eme sciecle, Les hors-série de Association Internationale des Collectionneurs de Timbres-Poste du Laos. Juin 2013 - n 5 (https:// dl.dropboxusercontent.com/u/25795783/Article\%20Peter\%20HAUFF\%20-\%20201305-26.pdf , norsk oversettelse https://www.dropbox.com/sh/oudm924ozat40yn/AAA3NEiVzXp0qLtRlYajCPtya/Strobino\%20Peter\%20Hauff\%20oversatt.pdf ).

Unique Passport, http://www.uniquepassport.com/Mekong cruise.php 